\title{
PENINGKATAN PRESTASI BELAJAR WRITTING MELALUI PENGGUNAAN MODEL EXPERIENTIAL LEARNING TARUNA TEKNIK TELEKOMUNIKASI DAN NAVIGASI UDARA POLITEKNIK PENERBANGAN SURABAYA TAHUN 2017/2018
}

\author{
Oleh : \\ Fatmawati \\ Anton Budiarto \\ Politeknik Penerbangan Surabaya \\ Jl. Jemur Andayani I/73, Surabaya 60236 \\ Email: fatmawati.0280@gmail.com
}

\begin{abstract}
ABSTRAK
Pembelajaran yang dirancang oleh dosen harus menggunakan model yang sesuai dengan situasi atau kondisi pembelajaran, media yang digunakan dan kompetensi yang ingin dicapai sehingga tercipta pembelajaran efektif, efesien dan menyenangkan bagi taruna yang belajar dan pada akhirnya taruna mendapatkan pengalaman yang bermakna bagi dirinya. Peneliti ingin mengetahui peningkatan prestasi belajar Writing melalui penggunaan Model Experiential Learning Taruna Telekomunikasi dan Navigasi Udara Poltekbang Surabaya. Saat belajar Writting seringkali taruna melakukan kesalahan saat membuat dan menggunakan kata kata tentang music, movies, TV programs, entertainer, invitations, excuses, date, and time. Hal ini dikarenakan dosen tidak tepat dalam memilih model pembelajaran. Permasalahan mendasar dalam penelitian ini adalah sebagian besar Taruna Telekomunikasi dan Navigasi Udara Poltekbang Surabaya Tahun Pelajaran 2017/2018 kurang mampu dalam Writting. Tujuan yang diharapkan dari penelitian ini adalah untuk mengetahui apakah penggunaan Model Experiential Learning dapat meningkatkan prestasi belajar Writting Taruna Telekomunikasi dan Navigasi Udara Poltekbang Surabaya tahun pelajaran 2017/2018.
\end{abstract}

Kata Kunci: Model Experiential Learning, Prestasi Belajar Bahasa Inggris

\section{PENDAHULUAN}

Dosen sebagai kunci utama pembelajaran bagi mahasiswa, memiliki peran penting untuk mengarahkan mahasiswa guna mencapai kompetensi yang diinginkan. Pada hakikatnya pesan yang sama muncul dari setiap mahasiswa: bahwa dosen perlu cermat memantau kesesuaian antara pengajaran dan mahasiswa yang diajar (Kyriacou, 2009:88). Pembelajaran bahasa diharapkan membantu mahasiswa agar dapat mengenali siapa dirinya, lingkungannya, budayanya dan budaya orang lain, mengemukakan gagasan, pikiran dan perasaannya. Menulis dapat didefiniskan sebagai suatu kegiatan penyampaian pesan (komunikasi) dengan menggunakan bahasa tulis sebagai alat medianya (Suparno, 2008:3).

Pengalaman merupakan dasar dari seluruh pembelajaran (Purnami, 2013:99). Membangun pembelajaran berbasis pengalaman bisa dilakukan dengan cara diantaranya dengan pembelajaran dengan model Experiential learning untuk meningkatkan kemampuan menulis bagi Taruna Teknik Telekomunikasi dan Navigasi Udara. Artinya mengukur daya kemampuan serap ilmu masing-masing taruna. Model pembelajaran experiential learning merupakan model 
pembelajaran yang diharapkan dapat menciptakan proses belajar yang lebih bermakna. Dalam hal menulis ini, mahasiswa belajar membuat dan menggunakan kata kata tentang music, movies, TV programs, entertainer, invitations, excuses, date, and time dengan mengaitkan pengalamanpengalaman yang mereka alami lalu menuangkannya dalam bentuk tulisan.

Menurut (Pratiwi, 2009:19), manfaat model experiential learning antara lain: 1) meningkatkan semangat dan gairah untuk belajar, 2) membantu terciptanya suasana pembelajaran yang kondusif, 3) memunculkan rasa kegembiraan ketika pembelajaran berlangsung, 4) mendorong dan mengembangkan proses berpikir kreatif, 5) membantu siswa untuk dapat melihat sesuatu dalam perspektif yang berbeda, 6) memunculkan kesadaran akan kebutuhan untuk berubah, dan 7) memperkuat kesadaran diri mahasiswa.

Pengertian prestasi belajar adalah penguasaan pengetahuan atau keterampilan yang dikembangkan oleh mata pelajaran yang lazimnya ditunjukkan dengan nilai tes atau angka nilai yang diberikan oleh dosen” (Tim Penyusun Kamus Pusat Bahasa, 2008).

Berdasarkan latar belakang masalah di atas, maka rumusan masalah dalam penelitian tindakan kelas ini adalah: Bagaimana meningkatkan prestasi belajar Writting melalui penggunaan Model Experiential Learning Taruna Telekomunikasi dan Navigasi Udara angk.XA Poltekbang Surabaya? Penelitian tindakan kelas ini bertujuan untuk mendeskripsikan upaya dosen dalam meningkatkan prestasi belajar Writting melalui penggunaan Model Experiential Learning Taruna Telekomunikasi dan Navigasi Udara angk.XA Poltekbang Surabaya.

\section{METODE PENELITIAN}

Metode penelitian diperlukan dalam penelitian ini, untuk membantu alur pemikiran yang jelas pada jalannya penelitian. Penelitian ini menggunakan penelitian tindakan karena penelitian tindakan kelas adalah merupakan penelitian yang lebih sesuai dengan tugas pokok dan fungsi guru, meningkatkan kualitas pembelajaran, meningkatkan kualitas taruna, serta mencapai tujuan pembelajaran atau pendidikan. PTK (Penelitian Tindakan Kelas) atau Classroom Action Research $(C A R)$ yang merupakan bentuk kajian yang bersifat reflektif oleh pelaku tindakan, dilakukan untuk meningkatkan kematangan rasional dari tindakan-tindakan dalam melakukan tugas, memperdalam pemahaman terhadap tindakan-tindakan yang dilakukan itu, serta memperbaiki kondisi tempat pembelajaran tersebut dilakukan.

Pada setiap siklus, kegiatan yang dilakukan pada tahap perencanaan adalah: (a) melakukan pertemuan dengan teman sejawat selaku pengamat untuk membicarakan persiapan kegiatan pembelajaran yang dilakukan pada saat pembelajaran teks fungsional pendek mempergunakan Model Experiential Learning, (b) mendiskusikan dan menetapkan SAP yang akan diterapkan di kelas sebagai tindakan penelitian, (c) mempersiapkan bahan yang diperlukan untuk melaksanakan penelitian, (d) mempersiapkan waktu dan cara pelaksanaan, diskusi hasil pengamatan pada subyek penelitian, (e) mempersiapkan buku perekam data, (f) mempersiapkan perangkat tes hasil belajar pada siklus pertama.

Pelaksanaan tindakan pada setiap siklus adalah: (a) melaksanakan kegiatan pembelajaran berpedoman pada SAP yang telah dibuat. Secara lebih terinci sms penelitian yang diterapkan dapat dijelaskan sebagai berikut. Pembelajaran Writting menggunakan Model Experiential Learning dalanm Bahasa Inggris pada siklus pertama dan pada siklus kedua pesan ditambah dengan tayangan PowerPoint untuk memperjelas eksperimen. Kemudian, dosen mendiskusikan cara melaksanakan kegiatan pembelajaran dengan dosen pengamat. (b) melakukan penilaian menggunakan alat penilaian yang telah disediakan. 
Kegiatan saat observasi adalah: (a) teman sejawat mencatat semua aktivitas yang dilakukan oleh dosen dan taruna selama proses pembelajaran, yaitu mulai kegiatan awal hingga kegiatan akhir. (b) melakukan observasi dengan instrumen observasi.

Kegiatan saat refleksi adalah: (a) menganalisa catatan di lapangan dan jurnal harian sebagai hasil pengamatan dikaji dan direnungkan kembali, (b) data yang terkumpul dikaji secara komprehensif, (c) data dibahas bersama pengamat untuk mendapat kesamaan pandangan terhadap tindakan pada siklus pertama. (d) hasil refleksi dijadikan bahan untuk merevisi rencana tindakan selanjutnya.

Penelitian ini menggunakan penelitian tindakan karena penelitian tindakan kelas adalah merupakan penelitian yang lebih sesuai dengan tugas pokok dan fungsi dosen, meningkatkan kualitas pembelajaran, meningkatkan kualitas taruna, serta mencapai tujuan pembelajaran atau pendidikan. Dalam penelitian ini yang menjadi subyek penelitian adalah 24 Taruna Telekomunikasi dan Navigasi Udara angk.XA Poltekbang Surabaya Tahun Pelajaran 2017/2018. Penelitian ini dilaksanakan pada bulan Januari 2018. Metode pengumpulan data pada penelitian ini adalah observasi, tes, wawancara, dan catatan lapangan. Teknik analisis data yang dipergunakan adalah reduksi data, penyajian data, penarikan simpulan, serta verifikasi refleksi.

Adapun tes hasil belajar siswa diolah untuk mengukur ketuntasan dengan menggunakan rumus: Rumus ketuntasan belajar

Prestasi belajar dikatakan berhasil apabila siswa secara individual telah memperolah nilai 80 atau lebih, dan secara klasikal dikatakan tuntas belajar jika lebih dari $85 \%$ siswa mendapat nilai 80 atau lebih. Di samping itu dilakukan juga metode analisis deskriptif yang merupakan pemaparan dari hasil penerapan pembelajaran dengan Model Experiential Learning.

Rumus rata-rata $=\underline{\text { Jumlah nilai }}$

Jumlah taruna

\section{HASIL PENELITIAN}

Tabel 1 Deskripsi Hasil Belajar Bahasa Inggris Siklus Pertama

\begin{tabular}{ccccccccccc}
\hline No & music & movies & TV programs & entertainer & invitations & excuses & date & time & Total & Nilai \\
\hline 1 & 0 & 1 & 0 & 1 & 1 & 1 & 1 & 1 & 6 & 75 \\
\hline 2 & 1 & 0 & 1 & 1 & 1 & 1 & 1 & 1 & 7 & 87.5 \\
\hline 3 & 1 & 1 & 1 & 0 & 1 & 1 & 1 & 1 & 7 & 87.5 \\
\hline 4 & 0 & 1 & 0 & 1 & 1 & 1 & 1 & 1 & 6 & 75 \\
\hline 5 & 1 & 1 & 1 & 1 & 0 & 0 & 1 & 1 & 6 & 75 \\
\hline 6 & 1 & 0 & 1 & 1 & 1 & 1 & 1 & 1 & 7 & 87.5 \\
\hline 7 & 0 & 1 & 0 & 1 & 1 & 1 & 1 & 1 & 6 & 75 \\
\hline 8 & 1 & 1 & 1 & 0 & 1 & 0 & 1 & 1 & 6 & 75 \\
\hline 9 & 1 & 0 & 1 & 1 & 1 & 1 & 1 & 1 & 7 & 87.5 \\
\hline 10 & 1 & 1 & 1 & 0 & 1 & 1 & 1 & 1 & 7 & 87.5 \\
\hline 11 & 0 & 1 & 0 & 1 & 0 & 0 & 1 & 1 & 4 & 50 \\
\hline 12 & 1 & 0 & 1 & 1 & 1 & 1 & 1 & 1 & 7 & 87.5 \\
\hline 13 & 1 & 1 & 1 & 0 & 1 & 1 & 1 & 1 & 7 & 87.5 \\
\hline 14 & 0 & 0 & 1 & 1 & 0 & 1 & 1 & 1 & 5 & 62.5 \\
\hline 15 & 1 & 1 & 0 & 1 & 1 & 0 & 1 & 1 & 6 & 75 \\
\hline 16 & 1 & 0 & 1 & 1 & 0 & 1 & 1 & 1 & 6 & 75 \\
\hline 17 & 0 & 1 & 1 & 1 & 1 & 1 & 1 & 1 & 7 & 87.5 \\
\hline 18 & 1 & 1 & 1 & 0 & 1 & 1 & 1 & 1 & 7 & 87.5 \\
\hline
\end{tabular}




\begin{tabular}{ccccccccccc}
\hline 19 & 1 & 0 & 1 & 1 & 0 & 1 & 1 & 1 & 6 & 75 \\
\hline 20 & 0 & 1 & 1 & 1 & 1 & 1 & 1 & 1 & 7 & 87.5 \\
\hline 21 & 1 & 1 & 0 & 1 & 1 & 0 & 1 & 1 & 6 & 75 \\
\hline 22 & 1 & 0 & 1 & 1 & 1 & 1 & 1 & 1 & 7 & 87.5 \\
\hline 23 & 0 & 1 & 0 & 1 & 0 & 1 & 1 & 1 & 5 & 62.5 \\
\hline 24 & 1 & 1 & 0 & 1 & 1 & 1 & 1 & 1 & 7 & 87.5 \\
\hline
\end{tabular}

Berdasarkan hasil penelitian, data tentang prestasi belajar taruna pada saat siklus pertama disajikan pada tabel berikut ini. Berdasarkan data hasil penelitian pada siklus pertama mengenai hasil belajar bahasa Inggris taruna di bidang Writting dengan menggunakan model experiential learning, nilai tertinggi yang diperoleh responden adalah 87,5, nilai terendah adalah 50, dan nilai rata-rata hasil belajar bahasa Inggris adalah 79,17.

Tabel 2 Deskripsi Hasil Belajar Bahasa Inggris Siklus Kedua

\begin{tabular}{ccccccccccc}
\hline No & music & movies & TV programs & entertainer & invitations & excuses & date & time & Total & Nilai \\
\hline 1 & 1 & 1 & 0 & 1 & 1 & 1 & 1 & 1 & 7 & 87.5 \\
\hline 2 & 1 & 0 & 1 & 1 & 1 & 1 & 1 & 1 & 7 & 87.5 \\
\hline 3 & 1 & 1 & 1 & 1 & 1 & 1 & 1 & 1 & 8 & 100 \\
\hline 4 & 1 & 1 & 0 & 1 & 1 & 1 & 1 & 1 & 7 & 87.5 \\
\hline 5 & 1 & 1 & 1 & 1 & 1 & 1 & 1 & 1 & 8 & 100 \\
\hline 6 & 1 & 0 & 1 & 1 & 1 & 1 & 1 & 1 & 7 & 87.5 \\
\hline 7 & 1 & 1 & 0 & 1 & 1 & 1 & 1 & 1 & 7 & 87.5 \\
\hline 8 & 1 & 1 & 1 & 1 & 1 & 1 & 1 & 1 & 8 & 100 \\
\hline 9 & 1 & 0 & 1 & 1 & 1 & 1 & 1 & 1 & 7 & 87.5 \\
\hline 10 & 1 & 1 & 1 & 1 & 1 & 1 & 1 & 1 & 8 & 100 \\
\hline 11 & 1 & 1 & 0 & 1 & 1 & 1 & 1 & 1 & 7 & 87.5 \\
\hline 12 & 1 & 0 & 1 & 1 & 1 & 1 & 1 & 1 & 7 & 87.5 \\
\hline 13 & 1 & 1 & 1 & 1 & 1 & 1 & 1 & 1 & 8 & 100 \\
\hline 14 & 1 & 0 & 1 & 1 & 1 & 1 & 1 & 1 & 7 & 87.5 \\
\hline 15 & 1 & 1 & 0 & 1 & 1 & 1 & 1 & 1 & 7 & 87.5 \\
\hline 16 & 1 & 0 & 1 & 1 & 1 & 1 & 1 & 1 & 7 & 87.5 \\
\hline 17 & 1 & 1 & 1 & 1 & 1 & 1 & 1 & 1 & 8 & 100 \\
\hline 18 & 1 & 1 & 1 & 1 & 1 & 1 & 1 & 1 & 8 & 100 \\
\hline 19 & 1 & 0 & 1 & 1 & 1 & 1 & 1 & 1 & 7 & 87.5 \\
\hline 20 & 1 & 1 & 1 & 1 & 1 & 1 & 1 & 1 & 8 & 100 \\
\hline 21 & 1 & 1 & 0 & 1 & 1 & 1 & 1 & 1 & 7 & 87.5 \\
\hline 22 & 1 & 0 & 1 & 1 & 1 & 1 & 1 & 1 & 7 & 87.5 \\
\hline 23 & 1 & 1 & 0 & 1 & 1 & 1 & 1 & 1 & 7 & 87.5 \\
\hline 24 & 1 & 1 & 0 & 1 & 1 & 1 & 1 & 1 & 7 & 87.5 \\
\hline & & & & & & & & & 91.67 \\
\hline
\end{tabular}

Berdasarkan hasil penelitian, data tentang prestasi belajar taruna pada saat siklus kedua disajikan pada tabel berikut ini. Berdasarkan data hasil penelitian pada siklus kedua mengenai hasil belajar bahasa Inggris taruna di bidang Writting dengan menggunakan model experiential learning ditambah dengan tayangan PowerPoint untuk memperjelas eksperimen, nilai tertinggi yang diperoleh responden adalah 100 , nilai terendah adalah 87,5, dan nilai rata-rata hasil belajar bahasa Inggris adalah 91,67. Kualitas proses pembelajaran selama siklus pertama, dan siklus kedua disajikan pada ketiga tabel berikut. 
Tabel 3 Kriteria Kualitas Suasana Pembelajaran Dalam Kelas :

\begin{tabular}{rrrrl}
\hline \multirow{5}{*}{ Nilai } & 4,00 & s.d & 5,0 & Sangat Baik \\
\cline { 2 - 5 } & 3,00 & s.d & 3,99 & Baik \\
\cline { 2 - 5 } & 2,00 & s.d & 2,99 & Cukup \\
\cline { 2 - 5 } & 1,00 & s.d & 1,99 & Kurang \\
\cline { 2 - 5 } & & $<$ & 1,00 & Sangat Kurang \\
\hline
\end{tabular}

Di atas adalah penentuan kriteria suasana pembelajaran dalam kelas yang dicatat saat observasi penelitian tindakan berlangsung.

Tabel 4 Kualitas Proses Pembelajaran Selama Siklus Pertama

\begin{tabular}{cccc}
\hline NO & ASPEK & SKOR & KUALITAS \\
\hline 1. & Suasana Pembelajaran & 3.00 & Baik \\
\hline 2. & Tanggung Jawab & 3.00 & Baik \\
\hline 3. & Rasa Percaya Diri & 3.00 & Baik \\
\hline 4. & Fokus Kegiatan & 3.00 & Baik \\
\hline \multicolumn{3}{c}{ Rata-Rata Nilai } \\
& 3.00 & Baik \\
\hline
\end{tabular}

Tabel 5 Kualitas Pembelajaran Selama Siklus Kedua

\begin{tabular}{cccc}
\hline NO & ASPEK & SKOR & KUALITAS \\
\hline 1. & Suasana Pembelajaran & 4,00 & Sangat Baik \\
\hline 2. & Tanggung Jawab & 4.00 & Sangat Baik \\
\hline 3. & Rasa Percaya Diri & 4.00 & Sangat Baik \\
\hline 4. & Fokus Kegiatan & 4.00 & Sangat Baik \\
\hline & Rata-Rata Nilai & 4.00 & Sangat Baik
\end{tabular}

Kualitas Proses Pembelajaran

Kriteria di atas yaitu yang mencakup suasana pembelajaran, tanggung jawab, rasa percaya diri, dan fokus kegiatan digunakan untuk mengetahui kualitas pembelajaran di dalam kelas.Tampaklah bahwa penggunaan Model Experiential Learning telah meningkatkan kualitas pembelajaran. Nilai rata-rata kualitas pembelajaran pada Siklus 1 sebesar 3,00, dan pada Siklus 2 adalah 4.00 .

\section{SIMPULAN}

Simpulan yang dapat diambil dari penelitian ini adalah:

Taruna Telekomunikasi dan Navigasi Udara angk.XA Poltekbang Surabaya mengalami ketuntasan belajar dalam materi Writting (nilai $\geq 80$ ). Berdasarkan data hasil penelitian pada siklus pertama mengenai hasil belajar bahasa Inggris taruna di bidang Writting dengan menggunakan model experiential learning, nilai tertinggi yang diperoleh responden adalah 87,5 dan nilai terendah adalah 50, dan nilai rata-rata hasil belajar bahasa Inggris adalah 79,17. Berdasarkan data hasil penelitian pada siklus kedua mengenai hasil belajar bahasa Inggris taruna di bidang Writting dengan menggunakan model experiential Learning ditambah dengan tayangan PowerPoint untuk memperjelas eksperimen, nilai tertinggi yang diperoleh responden adalah 100 , nilai terendah adalah 87,5 dan nilai rata-rata hasil belajar bahasa Inggris adalah 91,67. Pada siklus pertama ini yang tuntas ada 12 taruna $(50,00 \%)$ yang tidak tuntas ada 12 taruna $(50,00 \%)$. Pada siklus kedua 
yang tuntas ada 24 taruna (100\%) dan tidak ada yang tidak tuntas. Kualitas pembelajaran meningkat dalam lembar observasi. Kualitas pembelajaran yang mencakup suasana pembelajaran, tanggung jawab, rasa percaya diri, dan fokus kegiatan digunakan untuk mengetahui kualitas pembelajaran di dalam kelas. Tampaklah bahwa penggunaan Model Experiential Learning telah meningkatkan kualitas pembelajaran. Nilai rata-rata kualitas pembelajaran pada Siklus 1 sebesar 3,00, dan pada Siklus 2 adalah 4,00.

\section{DAFTAR PUSTAKA}

Davis. 2011. 5-step experiential learning cycle definitions. California: University of California Djamarah, Syaiful Bahri. 2012. Strategi Belajar Mengajar. Jakarta: PT Rineka Cipta

Haryanto. 2012. Pengertian Media Pembelajaran. http://belajarpsikologi.com/pengertian-mediapembelajaran/

Pratiwi, Heny (2009). Pembelajaran Berbasis Pengalaman. [Online]. Tersedia: http://henypratiwi.wordpress.com/2009/07/24/eksperiensial learning/,[16 Febuari 2016]

Purnami. 2013. "Implementasi Metode Experiential Learning dalam pengembangan Softskills Mahasiswa yang Menunjang Integrasi Teknologi, Manajemen dan Bisnis" Jurnal Penelitian Pendidikan, Vol. 14 No. 1, April 2013

Silberman, M. 2014. Active Learning 101 Cara Belajar Siswa Aktif. Translated by Raisul Muttaqien. 2014. Bandung : Nuansa Cendekia.

Suparno \& Yunus, Mohammad. 2008. Ketrampilan Dasar Menulis. Jakarta: Universitas Terbuka.

Trianto .2010.. Mendesain Model Pembelajaran Inovatif-Progresif. Jakarta: Kencana 